Article

\title{
Gold-Based Nanoparticles on Amino-Functionalized Mesoporous Silica Supports as Nanozymes for Glucose Oxidation
}

\author{
M. Carmen Ortega-Liebana ${ }^{1,2,+}$, Javier Bonet-Aleta ${ }^{1,2,3} \mathbb{C}^{\mathbb{C}}$, Jose L. Hueso ${ }^{1,2,3, *}$ and \\ Jesus Santamaria $1,2,3, *$ \\ 1 Institute of Nanoscience of Aragon (INA) and Department of Chemical and Environmental Engineering, \\ C/Poeta Mariano Esquillor, s/n; Campus Rio Ebro, Edificio I+D, 50018 Zaragoza, Spain; \\ mc.ortega@ed.ac.uk (M.C.O.-L.); jbaleta@unizar.es (J.B.-A.) \\ 2 Networking Research Center on Bioengineering, Biomaterials and Nanomedicine (CIBER-BBN), \\ 28029 Madrid, Spain \\ 3 Instituto de Ciencia de Materiales de Aragon (ICMA); Consejo Superior de Investigaciones \\ Cientificas (CSIC-University of Zaragoza), 50018 Zaragoza, Spain \\ * Correspondence: jlhueso@unizar.es (J.L.H.); jesus.santamaria@unizar.es (J.S.) \\ + Present address: Cancer Research UK Edinburgh Centre, University of Edinburgh, Crewe Road South, \\ Edinburgh EH4 2XU, UK.
}

Received: 18 February 2020; Accepted: 13 March 2020; Published: 16 March 2020

check for updates

\begin{abstract}
The transformation of glucose represents a topic of great interest at different levels. In the first place, glucose is currently conceived as a green feedstock for the sustainable production of chemicals. Secondly, the depletion of glucose at the cellular level is currently envisioned as a promising strategy to treat and alter the erratic metabolism of tumoral cells. The use of natural enzymes offers multiple advantages in terms of specificity towards the glucose substrate but may lack sufficient robustness and recyclability beyond the optimal operating conditions of these natural systems. In the present work, we have evaluated the potential use of an inorganic based nanohybrid containing gold nanoparticles supported onto ordered mesoporous supports. We have performed different assays that corroborate the enzyme-mimicking response of these inorganic surrogates towards the selective conversion of glucose into gluconic acid and hydrogen peroxide. Moreover, we conclude that these enzyme-like mimicking surrogates can operate at different $\mathrm{pH}$ ranges and under mild reaction conditions, can be recycled multiple times and maintain excellent catalytic response in comparison with other gold-based catalysts.
\end{abstract}

Keywords: gold; nanozymes; enzyme-mimicking; glucose oxidation; mesoporous silica; surface functionalization

\section{Introduction}

Saccharides are abundant, renewable and sustainable chemical compounds that play a key role both at industrial level and in the metabolism of living beings [1,2]. Only in 2017, the United States produced about $27.5 \mathrm{M}$ tons of starch, the most plentiful polysaccharide on Earth, which was further used for industrial and food applications. The hydrolysis of starch over supported metal catalysts produces glucose as main product. For this reason, from a green-feedstock point of view all selective chemical transformations of glucose are industrially attractive to produce high value-added products [1] and have been widely studied [1-4]. Glucose oxidation yielding gluconic acid possesses a huge industrial importance in the manufacturing of water-soluble cleansing products, food and beverages additives or pharmaceutics and cosmetics. Currently, this industrial production of 
gluconic acid is achieved by fermentation using Aspergillus niger [3,5]. Enzyme-mediated processes face several drawbacks: (i) difficulties in recovery and recycling; (ii) high costs in product preparation and purification and (iii) the catalytic activity is often affected by minimal variations in the working environment $[2,6]$.

Transformation of glucose is also extremely important in biomedicine and multiple cancer therapy studies are currently focused on glucose-starvation strategies to alter the local environment and metabolism of tumor cells $[7,8]$. For these reasons, there is an increasing interest in developing alternative enzyme-like catalysts based on inorganic materials that can overcome intrinsic limitations of natural enzymes [5-7,9-11]. Several nanomaterials [8,11] have been developed in the recent years aiming to emulate different kind of natural enzymes and so-called artificial enzymes or "nanozymes" [10-12]. Catalase-like materials are usually based on metals or metal oxides, such as $\mathrm{Fe}, \mathrm{Pt}, \mathrm{Pd} \mathrm{Ag}$ or $\mathrm{Au}[4,6,11,13,14]$, which efficiently decompose $\mathrm{H}_{2} \mathrm{O}_{2}$ into $\mathrm{H}_{2} \mathrm{O}$ and $\mathrm{O}_{2}$. Cerium $[6,9,10]$ and carbon-based nanomaterials such as fullerenes $\left(\mathrm{C}_{60}\right)[15,16]$ were remarkably efficient removing superoxide anion $\left(\mathrm{O}_{2}{ }^{-}\right)$yielding $\mathrm{H}_{2} \mathrm{O}_{2}$ and $\mathrm{O}_{2}$, mimicking the activity of superoxide dismutase enzymes. Iron-based [11] and noble metal based ( $\mathrm{Au}$ [17-19], Ag [20], Pt [21] or Pd [22]) nanomaterials have been widely reported as active catalysts to mimic peroxidase activity by oxidizing a substrate with $\mathrm{H}_{2} \mathrm{O}_{2}$. Finally, the enzyme-like oxidase mimicking activity represents another important field of current developments. $\mathrm{Au}$ [23], $\mathrm{Pt}$ [24] or $\mathrm{Cu}$ [25] nanomaterials can use $\mathrm{O}_{2}$ to selectively oxidize a substrate, yielding $\mathrm{H}_{2} \mathrm{O}_{2}$ and the corresponding oxidation products. Nevertheless, the enzyme-like behavior for each material is affected by multiple and diverse factors, such as size, shape, $\mathrm{pH}$, temperature or surface coating, among others [26].

The first catalysts tested in the catalytic oxidation of glucose using $\mathrm{O}_{2}$ were $\mathrm{Pd}$ [26-28] and $\mathrm{Pt}$ [29-31] particles. Although some of them yielded $>99 \%$ gluconic acid, these materials suffered from oxidation and critical deactivation caused by adsorption of reaction products. The introduction of Bi [32] partially avoided the previous problems, but their reusability was not evaluated. Among these inorganic enzyme surrogates, Au particles [4,23,33-44] have been the most studied material since early 2000s for the selective oxidation of glucose to gluconic acid. Gold is much more resistant to $\mathrm{O}_{2}$ poisoning than previously cited elements [39] and reaction products have less affinity to adsorption process onto the Au surface [44] apart from being more active and selective [2,18,19]. However, the main drawback is the strong-dependence of catalytic activity on Au surface and particle size [44], being dramatically affected by sintering phenomena [37]. Typically, Au NPs-mediated catalytic oxidation of glucose (Scheme 1) is performed in neutral to basic medium $(\mathrm{pH}=7-9)$. At this $\mathrm{pH}$, the open and more reactive tautomer is promoted [28] and the protonation of carboxyl groups of the products is avoided, which may easily remain adsorbed onto Au surfaces [44]. While regular enzymatic pathways suggest the formation of an additional $\delta$-gluconolactone intermediate [45], gold mimicking surrogates may follow other mechanisms involving a nucleophilic attack of $\mathrm{Au}-\mathrm{O}^{-}$sites that would ease the conversion into gluconic acid under milder experimental conditions [46].

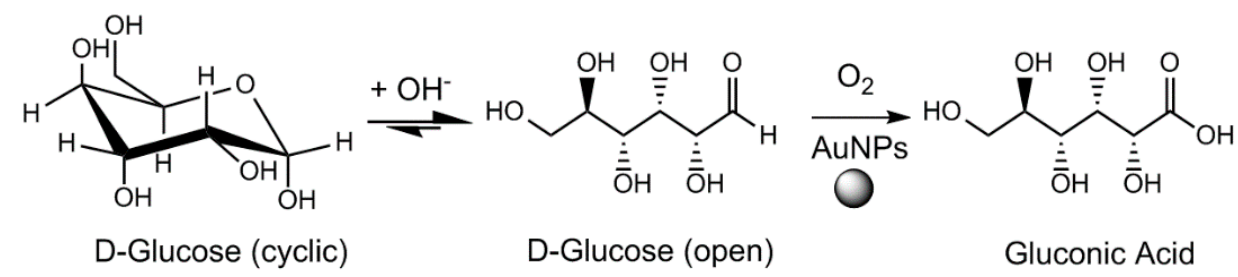

Scheme 1. pH dependent equilibrium and Au-mediated catalytic oxidation of glucose.

Analogously, temperature has also shown a positive impact on the rate and selectivity of the glucose oxidation reaction [44,47]. Although the use of a basic medium favors the glucose oxidation reaction and the stability of AuNPs [44], base-free conditions are still desired from the green chemistry, industrial and biomedicine point of view $[47,48]$. Therefore, it is necessary to improve the AuNPs 
stability in absence of basic conditions with the selection of suitable stabilizing agents [48] or after immobilization in different functional supports [49].

Several supports have been used for $\mathrm{Au}$ NPs deposition and applied in the catalytic oxidation of glucose including carbon-based materials [38,50-53], $\mathrm{Al}_{2} \mathrm{O}_{3}$ [42,54], $\mathrm{CeO}_{2}[38,39,52], \mathrm{ZrO}_{2}$ [55], $\mathrm{TiO}_{2}[28,41]$, mesoporous $\mathrm{SiO}_{2}$ [50] or polymers such as poly(methyl methacrylate), polystyrene or polyaniline [43], achieving in most of the cases $>80 \%$ of glucose conversion and $>90 \%$ selectivity for gluconic acid. The catalyst preparation method plays a key role in the catalytic activity [40]. The nature of Au-support interactions is also essential to ensure the stability of the catalytic system $[36,56]$. For instance, supports with high density of -OH groups on their surface promote the anchoring of $\mathrm{Au}$ NPs $[27,57]$. Likewise, $-\mathrm{NH}_{2}$ surface functional groups can endorse stronger affinity with AuNPs by electrostatic attraction thereby resulting in a more efficient immobilization of both the active metallic nanoparticles and the glucose sustrate [58-60].

In this work, we describe the synthesis of an amino-functionalized mesoporous silica nanoplatform decorated with small gold nanoparticles immobilized by electrostatic attraction. This hybrid Au-silica nanohybrid has been evaluated as a potential enzyme surrogate with glucose-oxidase mimicking response. Multiple reaction conditions have been thoroughly explored to identify the best performing scenario and the main reaction products (i.e., gluconic acid and hydrogen peroxide) expected from the selective oxidation of glucose. Furthermore, this work addresses different colorimetric assays to identify these main reaction products and shows competitive catalytic results working under mild, environmentally friendly conditions that are favorable for environmental and biomedical targeted applications.

\section{Results and Discussion}

\subsection{Synthesis and Characterization of Gold-Mesoporous Silica Heteronanostructures}

Figure 1a summarizes the different synthesis stages required to fabricate the gold-based nanohybrids. The first step (denoted as (i) in Figure 1a) consisted on the preparation of the gold nanoparticles (Au-NPs). A phosphonium derived salt, tetrakis(hydroxymethyl) phosphonium chloride (THPC), was employed as reducing and stabilizing ligand of the Au NPs. The use of this ionic stabilizing agent has been previously reported by Duff et al. [61] and our group $[49,62,63]$ as a successful alternative to poly-alcohols and other polymeric stabilizers with greater steric hindrance [62]. Cs-corrected Scanning Transmission Electron Microscopy (STEM) images demonstrated the formation of crystalline Au NPs with average diameters below $5 \mathrm{~nm}$ (Figure 1c). The second step (denoted as (ii) in Figure 1a) consisted on the synthesis of nanostructured silica hosts containing ordered mesoporous channels as demonstrated by TEM inspection (Figure 1d,e). These silica spheres were functionalized with an amino-grafting agent (see the Materials and Methods section for further details) containing $-\mathrm{NH}_{2}$ terminal groups ( $\sim 8 \% \mathrm{wt}$. according to thermogravimetric analysis and considered optimal to keep a good colloidal and thermal stability $[59,64])$ and Si-O bonds able to attach on the surface of the silica spheres $[49,65,66]$.

The final step (see (iii) in Figure 1a) involved the gold seeding of the amino-functionalized silica hosts favored by the electrostatic attraction of positively charged $-\mathrm{NH}_{3}{ }^{+}$terminal groups and negatively charged Au NPs $[49,59,65,66]$. The negative charge of these type of Au NPs has been previously reported $[67,68]$ and tentatively attributed to the coexistence of $\mathrm{Au}-\mathrm{O}^{-}$surface bonds and chloride stabilizing ions [67-69]. TEM and STEM images (Figure 1f,g) confirmed the successful attachment of the Au NPs. Pore size restrictions limited the loading of the bigger Au NPs within the mesochannels. ICP analysis confirmed 1\% Au wt. loadings. Following this strategy, Au NPs are endowed with higher catalytic sites availability while preventing them from partially coarsening events typically observed in freestanding Au NPs of this nature [63]. Furthermore, providing a solid and stable silica support can facilitate the recovery of the catalytic Au NPs for their potential reusability and/or regeneration [59]. 

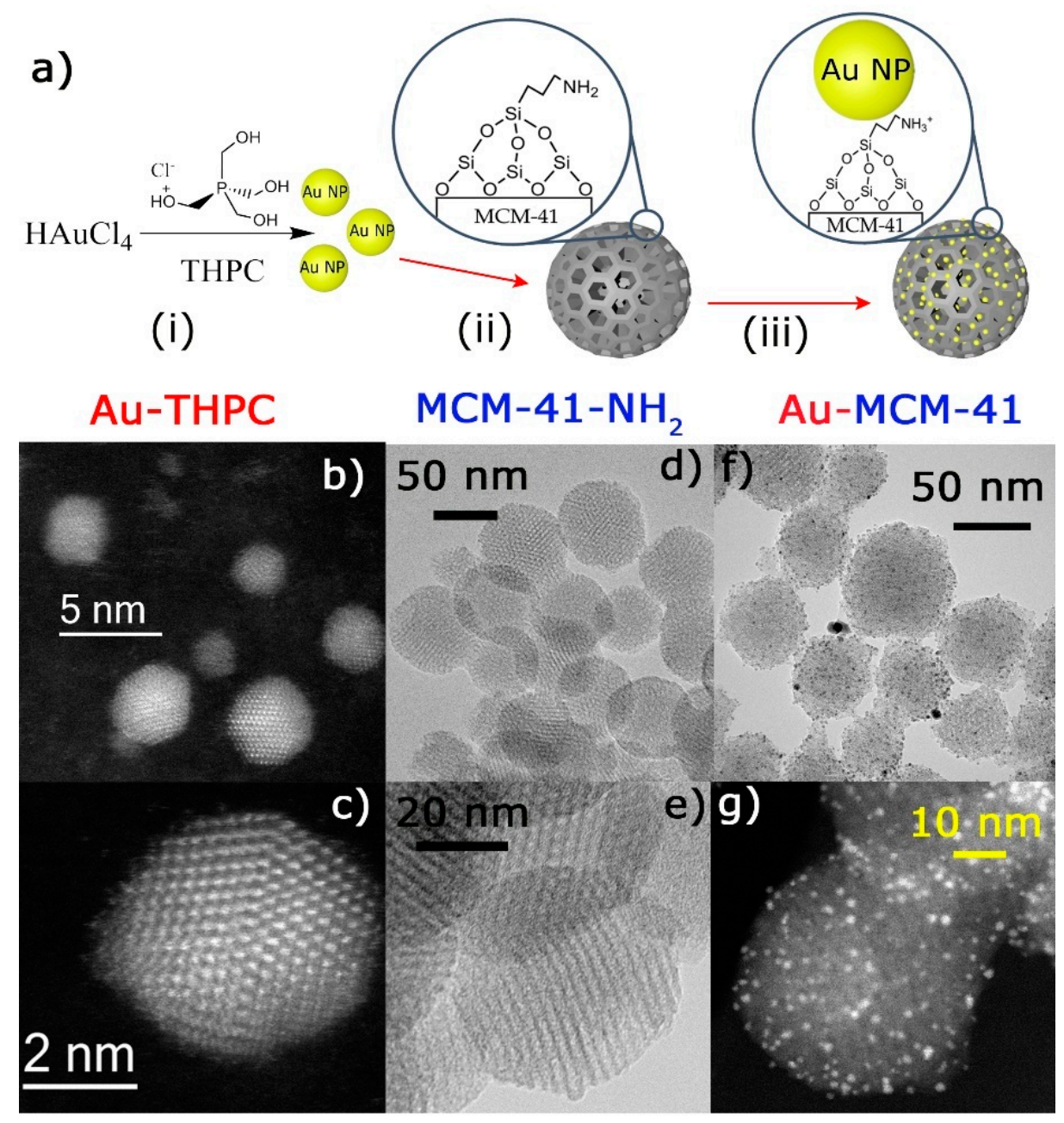

Figure 1. Synthesis and characterization of the Au-mesoporous silica hybrids: (a) Schematic description of the different synthesis stages including (i) the synthesis of the Au NPs with the aid of THPC [59,62]; (ii) the synthesis of the MCM-41 ordered mesoporous spheres and the amino-grafting step with APTES [49,65,66]; (iii) the gold seeding attachment by electrostatic attraction; (b-c) HAADF-STEM images of the individual Au NPs; (d-e) TEM images at different magnifications of the mesoporous silica supports showing the ordered organization of the mesochannels; (f-g) TEM and STEM images displaying the correct gold seeding process via electrostatic attraction and the formation of the Au-silica hybrid nanoparticles.

\subsection{Evaluation of Au-MCM-41 Nanohybrids as Enzyme-Mimicking Surrogates Towards Glucose Oxidation}

\subsubsection{Colorimetric Assays to Determine the Oxidation of Glucose into Gluconic Acid}

Au-MCM-41 hybrids were evaluated as inorganic structured materials mimicking the action of the natural enzyme glucose oxidase (GOx). Our enzyme-like surrogates were tested towards the aerobic oxidation of glucose under mild reaction conditions.

In order to evaluate the successful conversion of glucose into gluconic acid (hereafter GA) and hydrogen peroxide $\left(\mathrm{H}_{2} \mathrm{O}_{2}\right)$ (the expected reaction products), a combination of different colorimetric assays were carried out while exploring the influence of different experimental variables. First of all, formation of GA was indirectly validated by UV-Vis spectroscopy. GA can selectively react with hydroxylamine and a trivalent iron salt form a red-colored hydroxamate complex with a broad absorption centered at $505 \mathrm{~nm}$ (see Figure 2a,c) [12,70]. 
a)

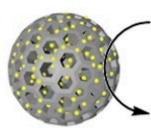
Glucose $+\mathrm{O}_{2}$

Au-MCM-41

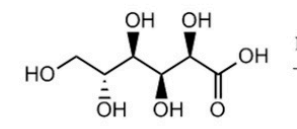

Gluconic Acid

Gluconic Hydroxamic Acid
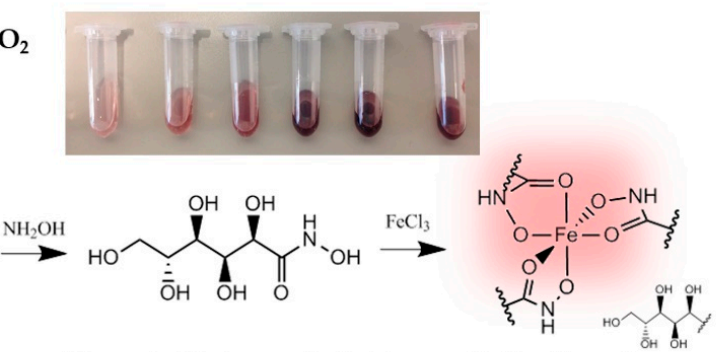

$\mathrm{Fe}^{\mathrm{III}}$ - Complex
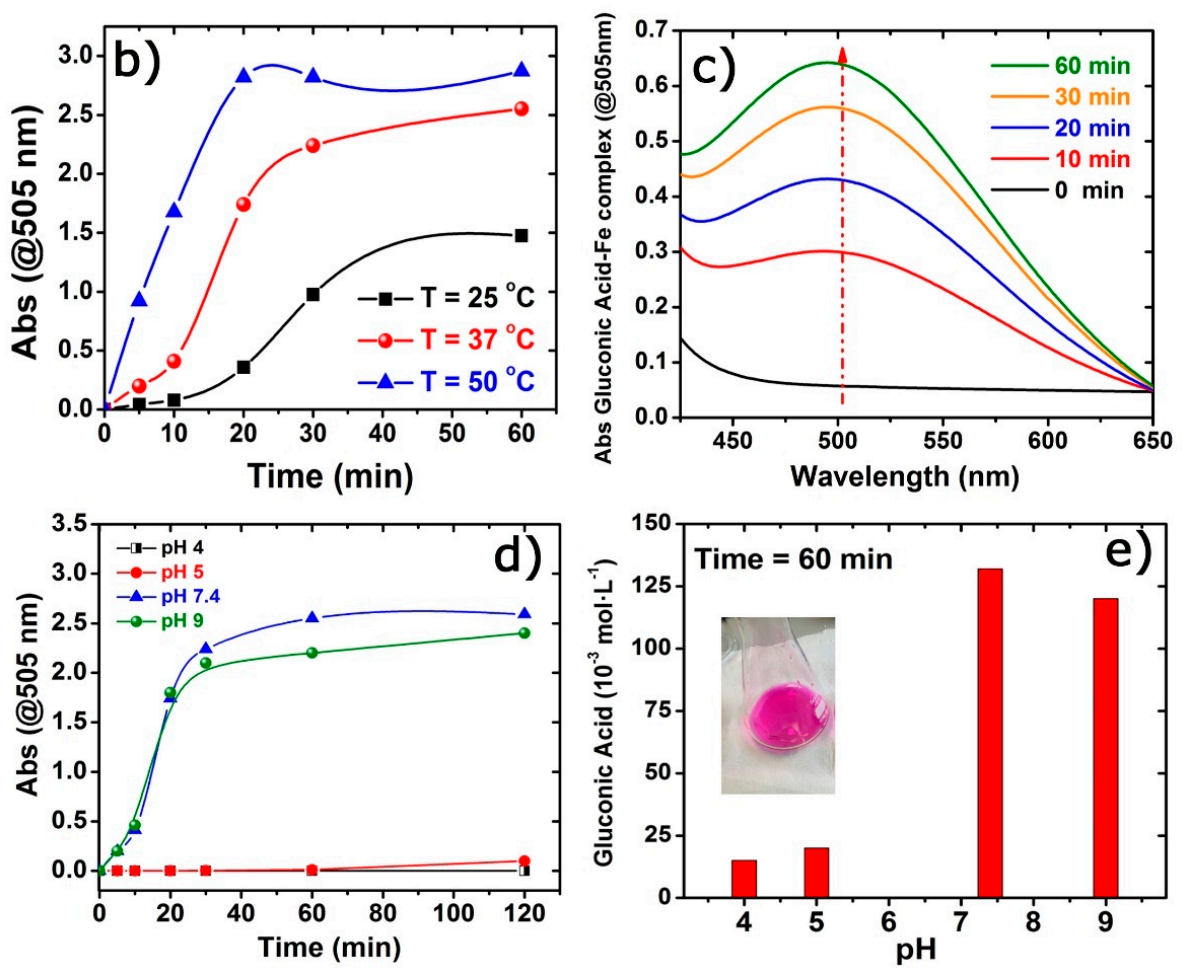

Figure 2. Determination of the presence of gluconic acid as one of the expected products retrieved from the oxidation of glucose in the presence of the enzyme-like gold-silica nanocatalyst: (a) Schematic display of the reaction of gluconic acid with hydroxylamine and trivalent Fe salt to form a red colored Fe-hydroxamate complex with a maximum absorbance centered at $505 \mathrm{~nm}$ (inset: digital image showing the evolution of the red-colored vials upon increasing reaction times related to increasing formation of gluconic acid); (b) Comparison of the maximum absorbance detected at different time intervals with different reaction temperatures and neutral $\mathrm{pH}=7.4$; (c) Representative UV-Vis spectra of the Fe-complex exhibiting an increase in the maximum absorbance centered at $505 \mathrm{~nm}$ after different reaction time intervals; (d) Comparison of the maximum absorbance detected at different time intervals and different $\mathrm{pH}$ conditions (temperatures fixed at $37^{\circ} \mathrm{C}$ ); (e) Concentrations of gluconic acid determined after colorimetric titration with $\mathrm{NaOH}$ and phenolphthalein as indicator (inset: digital image of the final color obtained after completing the neutralization of the gluconic acid with $\mathrm{NaOH}$ using phenolphthalein as colorimetric indicator). Experimental conditions: [catalyst] $=0.025 \mathrm{mg} / \mathrm{mL}$; [glucose] $=150 \mathrm{mM}$; reaction media buffered with $0.2 \mathrm{M}$ sodium acetate/acetic acid. Titration experiments were carried out using titration controls with known concentrations of commercial gluconic acid at pH adjusted to 4 .

The progressive formation of the Fe-complex was monitored at different reaction times under neutral $\mathrm{pH}$ conditions. Figure $2 \mathrm{~b}$ shows the positive influence of increasing the reaction temperature from 25 to $50{ }^{\circ} \mathrm{C}$ to increase the selective oxidation of glucose into GA that readily reacts to form the colored complex (see inset in Figure 2a,b). Likewise, the influence of the $\mathrm{pH}$ was further evaluated at a fixed reaction temperature of $37^{\circ} \mathrm{C}$. Figure $2 \mathrm{~d}$ shows the evolution of the absorption band of the 
hydroxamate complex at different $\mathrm{pH}$ values and confirms poorer performance of the Au-MCM-41 catalyst under basic conditions. It is also worth noting that no additional evolution was observed after $60 \mathrm{~min}$ of reaction. The formation and quantification of GA as reaction product was additionally determined by a colorimetric titration with sodium hydroxide and phenolphthalein [50,71]. According to the amounts of GA generated (see Figure 2e), the glucose conversion levels reached up to $85 \%$ at neutral $\mathrm{pH}$ conditions and $\mathrm{T}=37^{\circ} \mathrm{C}$ after $45 \mathrm{~min}$ of reaction. Titration methods confirmed the lower response under more acidic conditions as previously shown by UV-Vis spectroscopy (Figure 2d).

\subsubsection{Colorimetric Assays to Identify the Formation of Hydrogen Peroxide}

The other main reaction product expected from an enzyme-like glucose oxidase activity is typically hydrogen peroxide (Figure 3a). In order to assess its presence, two different colorimetric assays were performed [12]. The $\mathrm{H}_{2} \mathrm{O}_{2}$ generated during the oxidation of glucose was initially reduced with the aid of a horseradish peroxidase (HRP) enzyme (Figure 3a). In the first colorimetric assay, this reduction step induced the simultaneous oxidation of 3,3,5,5-tetramethylbenzidine (hereafter TMB) into its blueish colored derivative with a maximum absorption at $652 \mathrm{~nm}$ (Figure 3a,c). The systematic evaluation of the glucose oxidation under different $\mathrm{pH}$ conditions rendered a similar trend as observed for the detection of gluconic acid (vide infra Figure 3d). Neutral and basic media ensured the best time-dependent catalytic response of the Au-MCM-41 nanohybrids and the highest absorption values for the TMB(ox) dye (Figure 3b,c).
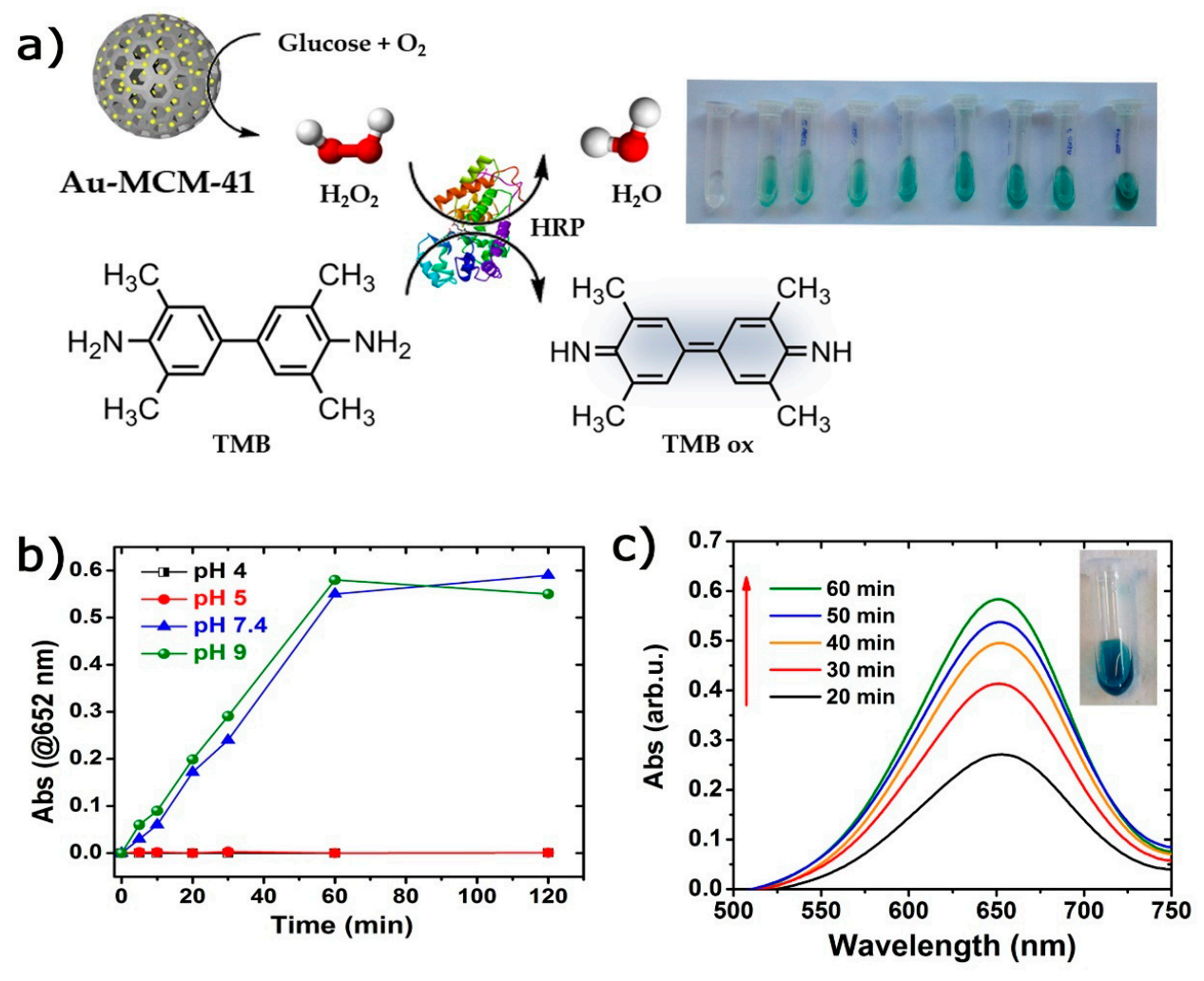

Figure 3. Colorimetric determination of the presence of hydrogen peroxide as reaction product retrieved from the glucose oxidation reaction (TMB assay): (a) Schematic display of the formation of hydrogen peroxide and its subsequent redox reaction mediated by a horseradish enzyme that readily reacts with TMB to render the blue colored oxidized derivative with maximum absorption spectrum centered at $652 \mathrm{~nm}$; (inset: digital image showing the evolution of the blue-colored vials upon increasing reaction times related to increasing formation of $\mathrm{H}_{2} \mathrm{O}_{2}$ ); (b) Time-dependent evolution of the maximum absorption 
of $\mathrm{TMB}(\mathrm{ox})$ at different $\mathrm{pH}$ conditions and keeping reaction temperatures of $37^{\circ} \mathrm{C}$; (c) Representative UV-Vis spectra of the TMBox dye after increasing reaction times (inset: digital image of the final solution after $60 \mathrm{~min}$ reaction); Experimental conditions: [catalyst] $=0.025 \mathrm{mg} / \mathrm{mL}$; [glucose] $=150 \mathrm{mM}$; reaction media buffered with $0.2 \mathrm{M}$ sodium acetate/acetic acid.

An analogous colorimetric assay mediated by the HRP enzyme to promote the simultaneous oxidation of a 2,2-azino-bis (3-ethylbenzothiozoline)-6-sulfonic acid salt (ABTS) into its blue colored oxidized derivative was also carried out (see scheme in Figure 4a). A similar behavior regarding the $\mathrm{pH}$ influence over time could be observed (Figure $4 \mathrm{~b}$ ). No catalytic activity could be detected at lower $\mathrm{pH}$ values of 4 or 5. Furthermore, no additional evolution of the maximum absorption spectrum at $415 \mathrm{~nm}$ (Figure 4c) was detected beyond the first $60 \mathrm{~min}$ of reaction under neutral or basic conditions (Figure 4b).
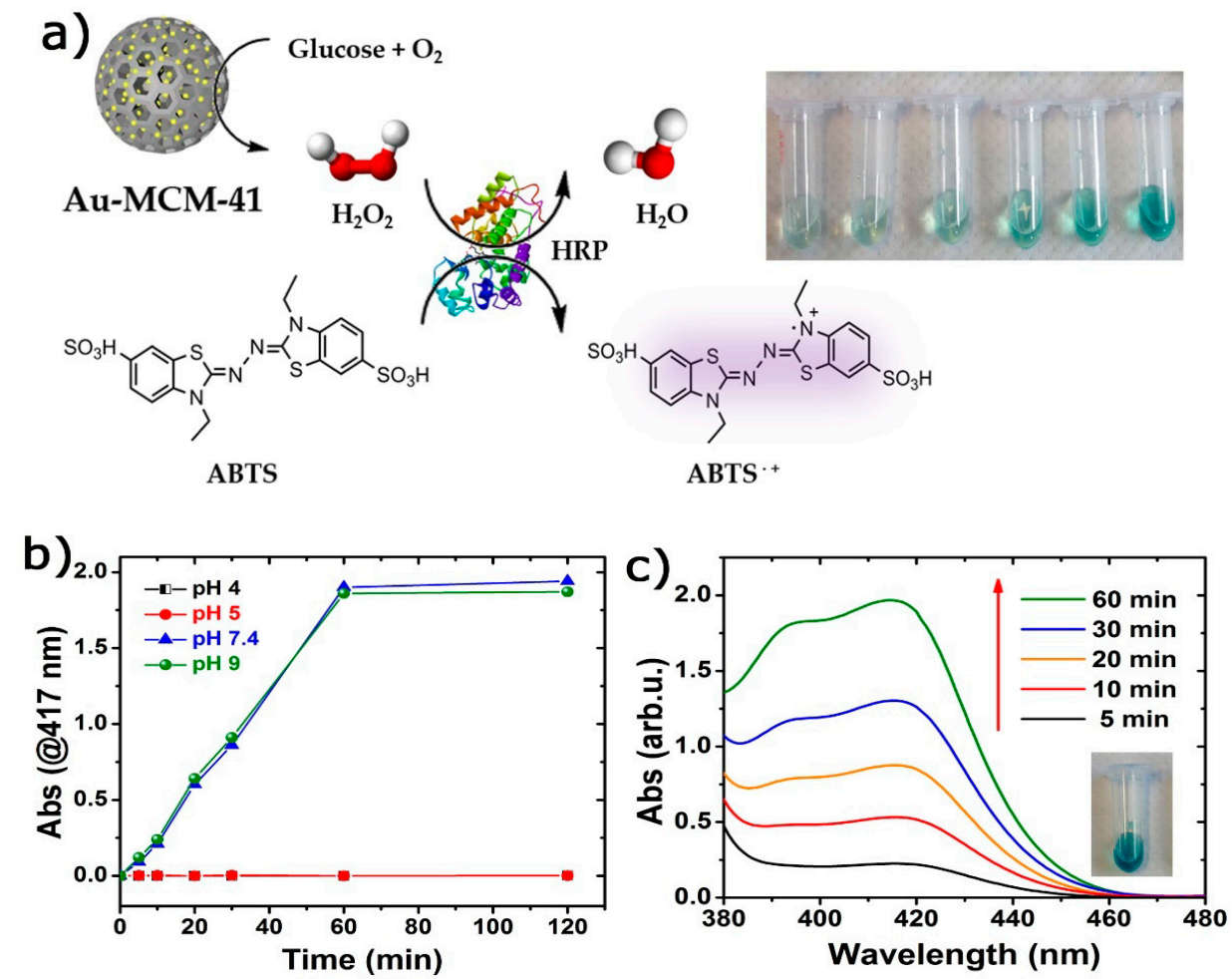

Figure 4. Colorimetric determination of the presence of hydrogen peroxide as reaction product retrieved from the glucose oxidation reaction (using the ABTS mediated assay): (a) Schematic display of the formation of hydrogen peroxide and its subsequent redox reaction mediated by a horseradish enzyme that readily reacts with ABTS to render the blue colored oxidized derivative with maximum absorption spectrum centered at $415 \mathrm{~nm}$; (inset: digital image showing the evolution of the blue-colored vials upon increasing reaction times related to increasing formation of $\mathrm{H}_{2} \mathrm{O}_{2}$ ); (b) Time-dependent evolution of the maximum absorption of ABTS(ox) at different $\mathrm{pH}$ conditions and keeping reaction temperatures of $37^{\circ} \mathrm{C}$; (c) Representative UV-Vis spectra of the ABTS(ox) molecule at increasing reaction time intervals; Experimental conditions: [catalyst] $=0.025 \mathrm{mg} / \mathrm{mL}$; [glucose] $=150 \mathrm{mM}$; reaction media buffered with $0.2 \mathrm{M}$ sodium acetate/acetic acid.

\subsubsection{Steady-State Kinetics and Recyclability Evaluation}

To quantify the glucose-oxidase enzyme mimicking activity of the Au-MCM-41 nanocatalyst, a kinetic study of the glucose conversion into gluconic acid was carried out. The kinetic parameters were determined after performing a series of experiments with increasing concentrations of glucose (Figure 5a) and adjusting the gluconic acid generated after $30 \mathrm{~min}$ of reaction by quantitative colorimetric assays that included $\mathrm{pH}$ titration $[50,71]$ and UV-Vis spectroscopy [70,72] (see Experimental section for 
further details). The data were fitted to a non-linear regression of the Michaelis-Menten equation and the apparent kinetic parameters were obtained using the Lineweaver-Burk double reciprocal plot as previously suggested by Gao et al. [73] (see inset in Figure 5a).

a)

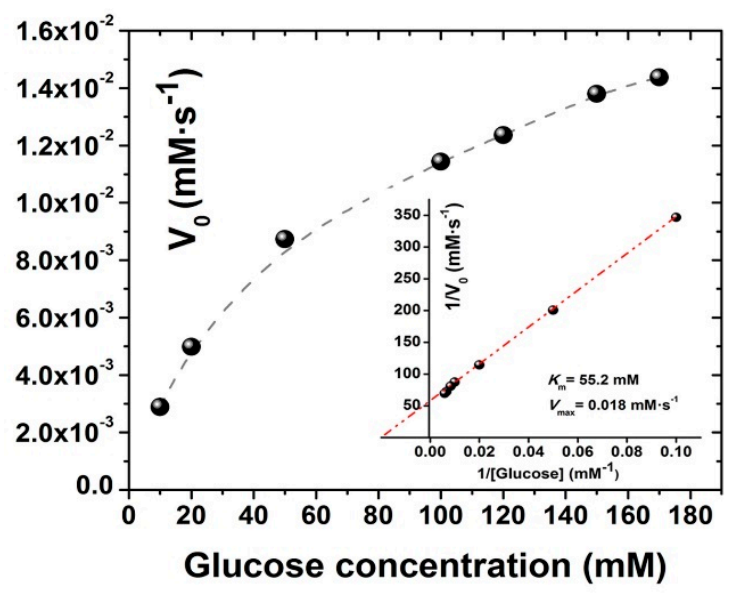

b)

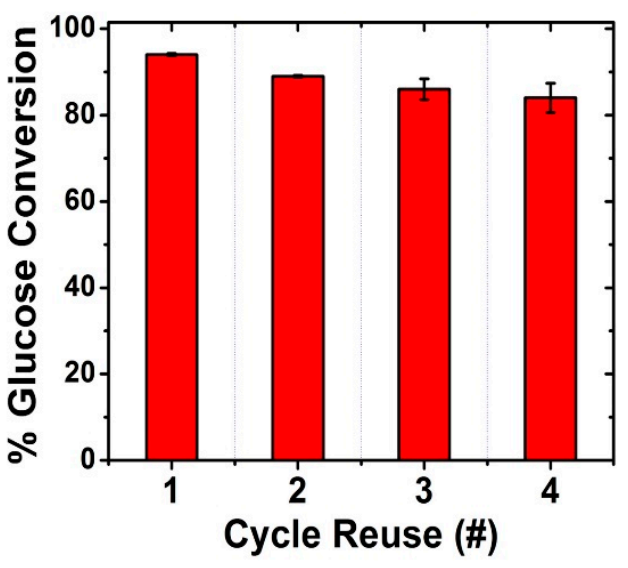

Figure 5. (a) Steady-state kinetic assay and evaluation of the conversion rates of glucose in the presence of the enzyme-like gold-silica nanocatalyst using different substrate concentrations (fixed concentrations of glucose: 10, 20, 50, 100, 120, 150, $180 \mathrm{mM}$ ). The formation of Fe-hydroxamate complex after $30 \mathrm{~min}$ was evaluated for each concentration to plot the apparent reaction rate $\left(V_{\mathrm{o}}\right)$ and $1 / V_{\mathrm{o}}$; (inset: double-reciprocal plots of the glucose-oxidase mimicking activity of the nanocatalyst assuming a Lineweaver-Burk plot). Experimental details: [glucose] $=10-180 \mathrm{mM}$; [catalyst] $=0.025 \mathrm{mg} / \mathrm{mL}$; $\mathrm{pH}=7.4$ in $0.2 \mathrm{M}$ acetate/acetic buffer; temperature: $37^{\circ} \mathrm{C}$. (b) Reusability of the enzyme-like gold-silica nanocatalyst after 4 consecutive cycles. Experimental details: [glucose] $=150 \mathrm{mM}$; [catalyst] $=0.025 \mathrm{mg} / \mathrm{mL} ; \mathrm{pH}=7.4$ in $0.2 \mathrm{M}$ acetate/acetic buffer; temperature: $37^{\circ} \mathrm{C}$; the nanocatalyst was recovered by centrifugation.

An apparent Michaelis-Menten constant (defined as $\mathrm{K}_{\mathrm{m}}$ ) of $\sim 55 \mathrm{mM}$ and a maximum velocity $\left(V_{\max }\right)$ of $18 \times 10^{-6} \mathrm{M} / \mathrm{s}$ were determined (inset graph in Figure $5 \mathrm{a}$ ). This apparent $\mathrm{K}_{\mathrm{m}}$ constant is higher than other values reported for freestanding gold nanozymes $\left(K_{\mathrm{m}} \sim 7 \mathrm{mM}\right)$ [71], polymer-coated gold mimics $\left(\mathrm{K}_{\mathrm{m}} \sim 0.4 \mathrm{mM}\right)$ [19], gold-supported mimicking systems $\left(\mathrm{K}_{\mathrm{m}} \sim 27 \mathrm{mM}\right)$ [50] or the glucose oxidase (GOx) natural enzyme $\left(\mathrm{K}_{\mathrm{m}} \sim 5 \mathrm{mM}\right)$ [71]. According to this value, our Au-MCM-41 nanozymes show a slightly weaker affinity towards the glucose substrate $[19,50,71]$. Nevertheless, the corresponding catalytic activity $\left(\mathrm{K}_{\text {cat }}\right)$ defined by the coefficient $\mathrm{V}_{\max } /[$ concentration of catalyst] improves the values reported for natural GOx ( $\mathrm{K}_{\text {cat }} \sim 14.2 \mathrm{~s}^{-1} \mathrm{vs}$. $\mathrm{K}_{\text {cat }} \sim 9.7 \mathrm{~s}^{-1}$, respectively) and it is close to freestanding $\mathrm{Au}$ NPs $\left(\mathrm{K}_{\mathrm{cat}} \sim 18.5 \mathrm{~s}^{-1}\right)$ reported by Luo et al. [71]. From the catalytic standpoint, the enzyme-like Au-MCM-41 nanohybrids exhibit a very positive response probably due to the good accessibility and homogeneous distribution of the gold active sites in the mesoporous support. The glucose conversion levels achieved (85-92\% in less than $1 \mathrm{~h}$ of reaction) working under mild reaction conditions (in the absence of co-solvents or basic conditions and without high temperature or working pressure) are extremely competitive with current gold-based systems available in the literature and briefly summarized in Table 1 (vide infra).

It is also plausible that a controlled $\mathrm{O}_{2}$ feeding would have led to an even better performance. Still, it is a very positive outcome if a potential application to modify the microenvironment of tumoral cells (with low $\mathrm{O}_{2}$ concentration levels) is envisioned. As suggested by Cattaneo et al. [46] it is quite plausible that the reaction of glucose is strongly favored by the nucleophilic attack of glucose on $\mathrm{Au}-\mathrm{O}^{-}$ sites. This reaction would be favored at higher $\mathrm{pH}$ and temperatures but those requirements would be still less demanding than those reported in the regular enzymatic pathway, where the hydrolysis of the $\delta$-glucono-lactone is the rate-limiting step for gluconic acid generation [45]. Even though the 
final product is the same, the Au-based nanozyme may follow a different mechanism. Additional insights with the aid of Nuclear Magnetic Resonance (NMR) techniques and theoretical simulation studies can be noteworthy for the corroboration of these differences in reaction mechanisms between natural enzyme and artificial enzyme systems [45,46,53,74-76]. Furthermore, the silica mesoporous support provides not only a great active surface area for the accommodation of glucose but also a more favorable platform to facilitate the recovery and reutilization of the nanozyme than in freestanding systems. Figure $5 b$ illustrates the capability of these Au-silica hybrids to be reutilized in multiple consecutive reaction cycles with a minimal reduction of the glucose conversion levels, most likely attributable to an incomplete retrieval of all the catalyst from cycle to cycle.

Table 1. Selection of Au-based catalysts reported for glucose oxidation.

\begin{tabular}{|c|c|c|c|c|c|c|c|}
\hline Catalyst & $\begin{array}{l}\text { Glucose/Au } \\
(\mathrm{mol} / \mathrm{mol})\end{array}$ & {$[\text { Glucose }]_{0}$} & $\begin{array}{c}\mathrm{O}_{2} \\
(\mathrm{~mL} / \mathrm{min})\end{array}$ & $\mathrm{T}\left({ }^{\circ} \mathrm{C}\right)$ & $\mathrm{pH}$ & $\begin{array}{l}\text { \%Conversion } \\
\text { (react. time) }\end{array}$ & Ref. \\
\hline $1.0 \% \mathrm{Au} / \mathrm{C}$ & 100 & $0.20 \mathrm{M}$ & 20 & 40 & $\mathrm{BF}^{\mathrm{b}}$ & $80.0(18 \mathrm{~h})$ & [38] \\
\hline $1.0 \% \mathrm{Au} / \mathrm{C}$ & 1000 & $0.22 \mathrm{M}$ & 20 & 50 & 9.5 & $100(50 \mathrm{~min})$ & {$[23,55]$} \\
\hline $0.5 \% \mathrm{Au} / \mathrm{C}$ & 40,000 & $3.00 \mathrm{M}$ & 100 & 50 & 9.5 & $95.0(55 \mathrm{~min})$ & {$[55,77]$} \\
\hline $1.0 \% \mathrm{Au} / \mathrm{NPC}$ & 32,000 & $0.30 \mathrm{M}$ & 120 & 50 & 9.0 & $>99.0$ & [40] \\
\hline $2.0 \% \mathrm{Au} / \mathrm{C}$ & 100 & $0.20 \mathrm{M}$ & $0.1 \mathrm{MPa}$ & 40 & $\mathrm{BF}$ & $78.0(18 \mathrm{~h})$ & [38] \\
\hline $0.9 \% \mathrm{Au} / \mathrm{CMK}$ & $1050^{a}$ & $0.10 \mathrm{M}$ & $0.3 \mathrm{MPa}$ & 110 & $\mathrm{BF}$ & $92.0(2 \mathrm{~h})$ & [53] \\
\hline $1.0 \% \mathrm{Au} / \mathrm{Al}_{2} \mathrm{O}_{3}$ & 32,000 & $0.30 \mathrm{M}$ & 120 & 50 & 9.0 & $100(15 \mathrm{~min})^{a}$ & [35] \\
\hline $1.6 \% \mathrm{Au} / \mathrm{Al}_{2} \mathrm{O}_{3}$ & 100 & $0.20 \mathrm{M}$ & 20 & 120 & $\mathrm{BF}$ & $78.0(18 \mathrm{~min})$ & [39] \\
\hline $0.3 \% \mathrm{Au} / \mathrm{Al}_{2} \mathrm{O}_{3}$ & - & $0.10 \mathrm{M}$ & 500 & 40 & 9.0 & 100 & [33] \\
\hline $2.0 \% \mathrm{Au}-\mathrm{Mt} / \mathrm{CeAl}$ & 100 & $0.20 \mathrm{M}$ & $0.1 \mathrm{MPa}$ & 120 & $\mathrm{BF}$ & $>75(16 \mathrm{~h})$ & [78] \\
\hline $1.0 \% \mathrm{Au} / \mathrm{ZrO}_{2}$ & 32,000 & $0.30 \mathrm{M}$ & 120 & 50 & 9.0 & $100(12 \mathrm{~min})^{a}$ & [35] \\
\hline $\mathrm{Au} / \mathrm{TiNT}$ & 100 & $0.25 \mathrm{M}$ & SP 5 bar & 80 & 9.5 & $73.0(6 \mathrm{~h})$ & [27] \\
\hline AuPd/TiNT & 100 & $0.25 \mathrm{M}$ & SP 5 bar & 80 & 9.5 & $74.4(6 \mathrm{~h})$ & [27] \\
\hline $0.5 \% \mathrm{Au} / \mathrm{TiO}_{2}$ & 1000 & $0.10 \mathrm{M}$ & $1 \mathrm{MPa}$ & 110 & $\mathrm{BF}$ & $92.0(2 \mathrm{~h})$ & [42] \\
\hline $3.9 \% \mathrm{Au} / \mathrm{CeO}_{2}$ & 100 & $0.20 \mathrm{M}$ & 20 & 120 & $\mathrm{BF}$ & $70.0(18 \mathrm{~h})$ & [39] \\
\hline $0.9 \% \mathrm{Au} / \mathrm{meso} \mathrm{SiO}_{2}$ & $1080^{a}$ & $0.10 \mathrm{M}$ & $0.3 \mathrm{MPa}$ & 110 & $\mathrm{BF}$ & $67.0(2 \mathrm{~h})$ & [53] \\
\hline $1.0 \% \mathrm{Au} / \mathrm{MCM}-41$ & 118,200 & $0.15 \mathrm{M}$ & - & 37 & 7.4 & 85.0 (45 min $)$ & This work \\
\hline
\end{tabular}

\section{Materials and Methods}

\subsection{Chemicals}

Chemicals were used as received without further purification. Gold(III) chloride hydrate ( $\mathrm{HAuCl}_{4} \cdot 3 \mathrm{H}_{2} \mathrm{O}, 50 \%$ Au basis), Tetrakis(hydroxymethyl) phosphonium chloride solution (THPC, $80 \mathrm{wt} \%$, Aldrich, Germany), Sodium hydroxide ( $\mathrm{NaOH})$, Hexadecyltrimethylammonium bromide (CTABr, 96\%), Tetraethyl orthosilicate (TEOS, $\geq 99.0 \%$, GC), (3-aminopropyl)triethoxysilane (APTES, $99 \%$ ), Triethanolamine (TEA, $\geq 99.0 \%$, GC), D-(+)-glucose (ACS reagent), Peroxidase from horseradish (type VI-A), 2,2-azino-bis (3-ethylbenzothiozoline)-6-sulfonic acid diammonium salt (ABTS-( $\left.\mathrm{NH}_{4}\right)_{2}$ ), 98\% HPLC), 3,3,5,5-tetramethylbenzidine (TMB, 99\%), Iron (III) chloride hexahydrate $(97 \%)$, hydroxylamine solution ( $50 \mathrm{wt} \% \mathrm{H}_{2} \mathrm{O}, 99.999 \%$ ) were purchased from Sigma-Aldrich, Germany). Sodium hydroxide solutions were kept in well-washed polyethylene containers, and chloroauric acid solutions were excluded from the light. The solutions were prepared using ultrapure water which was purified by a Millipore Milli-Q system (Merck, Madrid, Spain).

\subsection{Synthesis of Gold Nanoparticles Using THPC as Reducing and Stabilizing Agent (Au-NPs)}

Ultrasmall Au-NPs were prepared as described previously elsewhere with slight modifications $[62,63]$. Successive charging of a $50 \mathrm{~mL}$ glass vial, while stirring, with $14 \mathrm{~mL}$ of distilled water and then, in order, portions of aqueous solutions of sodium hydroxide $(1 \mathrm{M}, 165 \mu \mathrm{L})$, the reducing agent THPC $(65 \mathrm{mM}, 333 \mu \mathrm{L})$, and the freshly dissolved chloroauric acid salt $(3 \mathrm{mg}, 1 \mathrm{~mL})$ results in the formation of orange-brown hydrosols of gold. Two minutes was allowed between the addition of THPC and that 
of chloroauric acid. The reaction mixture was stirred for 1 day at room temperature, protecting the mixture from light to prevent the photothermal decomposition of precursors [79]. Finally, the resulting colloid Au-NPs were stored in a refrigerator at $4{ }^{\circ} \mathrm{C}$ until further use.

\subsection{Synthesis of Amino-Functionalized Mesoporous Silica Supports (MCM-41 Type Material)}

Silica materials with hexagonally arranged uniform mesopores were synthesized using the previously reported approach $[59,80,81]$ for base catalysed sol gel condensation of TEOS in the presence of structure directing agent. MCM-41-like mesoporous nanoparticles were synthesized by the following procedure: CTAB $(1.00 \mathrm{~g}, 2.7 \mathrm{mmol})$ was first dissolved in deionized water $(1 \mathrm{~L})$. NaOHaq. $(2.00 \mathrm{M}$, $5 \mathrm{~mL})$ was added to the CTAB solution, and the temperature was adjusted to $80{ }^{\circ} \mathrm{C}$. TEOS $(7 \mathrm{~mL}$, $0.05 \mathrm{mmol}$ ) was then added drop-wise to the surfactant solution. The mixture was left to stir for $3 \mathrm{~h}$ to give a white precipitate. The solid product was centrifuged and washed with deionized water until a neutral $\mathrm{pH}$. Finally, the solid was dried. To prepare the final porous material, the as-synthesized solid were dissolved in acidic $\mathrm{EtOH}(100 \mathrm{~mL}$, and few drops of $\mathrm{HCl} 37 \%)$ for $12 \mathrm{~h}$ to remove the template phase. The precipitate was recovered by centrifugation at $20,000 \mathrm{~g}$ and thoroughly washed with distilled $\mathrm{H}_{2} \mathrm{O} / \mathrm{EtOH}(1: 1,2 \mathrm{x})$ and $\mathrm{EtOH}(2 \mathrm{x})$. Then the product was dried overnight under reduced pressure. Subsequently, primary amine groups were grafted on the surface of the mesochannels by condensation of 3-aminopropyltriethoxysilane (APTES), to favor electrostatic interactions between the MCM-41 nanoparticles and the Au-NPs [49,59,65,82]. Briefly, $0.50 \mathrm{~g}$ of MCM-41 material was dispersed in $10 \mathrm{~mL}$ of toluene, $100 \mu \mathrm{L}$ of TEA and $200 \mu \mathrm{L}$ of APTES. The reaction was refluxed for $24 \mathrm{~h}$, and the product was centrifuged and washed twice prior to total drying under vacuum for further use.

\subsection{Synthesis of the Au-MCM-41 Nanohybrids}

To prepare the gold-silica nanohybrid, $0.10 \mathrm{~g}$ of amino modified MCM-41 nanoparticles was dispersed in $10 \mathrm{~mL}$ of the Au-NCs stored suspension. The suspension was adjusted to $\mathrm{pH} 5$ and stirred at $20^{\circ} \mathrm{C}$ for $12 \mathrm{~h}$ in the dark. Subsequently, the product was collected by centrifugation, washed several times with water, and re-dispersed in water until further use. The synthesis of materials has been performed by the Platform of Production of Biomaterials and Nanoparticles of the NANOBIOSIS ICTS, more specifically by the Nanoparticle Synthesis Unit of the CIBER in BioEngineering, Biomaterials \& Nanomedicine (CIBER-BBN).

\subsection{Determination of Activity and Steady-State Kinetics of the Au-MCM-41 Nanohybrids}

The glucose oxidation reactions were carried out with temperature control in a thermoplate, equipped with a mechanical stirrer operating at $750 \mathrm{rpm}$, using a total volume of $100 \mathrm{~mL}$ and different glucose concentrations from 10 up to $180 \mathrm{mM}$. The concentration of the Au-MCM-41 nanocatalyst was $0.025 \mathrm{mg} / \mathrm{mL}$. Concentration of dissolved $\mathrm{O}_{2}$ was typically in the range of 6-8 mg/L (determined with an Orion Optical Dissolved $\mathrm{O}_{2}$ sensor, Thermo Scientific). The $\mathrm{pH}$ of the reaction mixture was held constant at 7.4. The kinetics of the catalytic reaction could be well adjusted to a typical Michaelis-Menten curve [70,72]. The Michaelis-Menten constant was calculated using the Lineweaver-Burk plot: $1 / \mathrm{V}_{0}=\left(\mathrm{K}_{\mathrm{m}} / \mathrm{V}_{\max }\right) \cdot(1 /[\mathrm{S}])+\left(1 / \mathrm{V}_{\max }\right)$, where $\mathrm{V}_{0}$ is the initial velocity, $\mathrm{V}_{\max }$ is the maximal reaction velocity, and [S] is the concentration of the substrate. The rate of the catalytic reaction was defined as the amount of generated product, gluconic acid, in a fixed time interval of $30 \mathrm{~min}$. The concentration of gluconic acid was determined via titration with $\mathrm{NaOH}(0.1 \mathrm{M})$ using phenolphthalein at $\mathrm{pH} 8.2$ as colorimetric $\mathrm{pH}$ indicator. Likewise, this reaction product, (i.e., gluconic acid), was also verified by reaction with hydroxylamine and a trivalent $\mathrm{Fe}^{\mathrm{III}}$ salt, leading to a red complex hydroxamate- $\mathrm{Fe}^{3+}$ (with a maximum absorbance at $505 \mathrm{~nm}$ ) [70]. Namely, $125 \mu \mathrm{L}$ of solution 1 ( $5 \mathrm{mmol} / \mathrm{L}$ EDTA and $0.15 \mathrm{mmol} / \mathrm{L}$ triethylamine in water) and $12.5 \mu \mathrm{L}$ of solution $2\left(3 \mathrm{~mol} / \mathrm{L} \mathrm{NH}_{2} \mathrm{OH}\right.$ in water) were added to $200 \mu \mathrm{L}$ of the supernatant centrifuged reaction solution, and the mixture was allowed to react for $25 \mathrm{~min}$. Finally, $62.5 \mu \mathrm{L}$ of solution $3\left(1 \mathrm{~mol} / \mathrm{L} \mathrm{HCl}, 0.1 \mathrm{~mol} / \mathrm{L} \mathrm{FeCl}_{3}\right.$, and $0.25 \mathrm{~mol} / \mathrm{L} \mathrm{CCl}_{3} \mathrm{COOH}$ in water) was added to the reaction medium, and reaction was incubated for another $5 \mathrm{~min}$ before spectral 
acquisition. Absorbance values from the Fe-complex at different reaction times and total gluconic acid concentrations were correlated using the Lambert-Beer law and a molar absorption coefficient of $61.2[50,70-72]$. In order to prevent the influence of the nanoparticles, the suspensions were previously centrifuged at $6000 \mathrm{rpm}$ in $2 \mathrm{~mL}$ Eppendorfs.

Hydrogen peroxide $\left(\mathrm{H}_{2} \mathrm{O}_{2}\right)$ was indirectly tested with the aid of a horseradish peroxidase (HRP) enzyme that selectively favored the reduction of the $\mathrm{H}_{2} \mathrm{O}_{2}$ present in solution and the simultaneous oxidation of ABTS or TMB with specific absorbances at 415 and $652 \mathrm{~nm}$, respectively [12,70,72]. In a standard procedure, $300 \mu \mathrm{L}$ of the filtered catalytic reaction solution was added to $50 \mu \mathrm{L}$ of $8 \mathrm{mM}$ ABTS and $50 \mu \mathrm{L}$ of $0.4 \mu \mathrm{g} / \mathrm{mL}$ HRP. The oxidation produced a green color with a major absorbance peak at $415 \mathrm{~nm}$ (final concentrations after dilutions for UV-Vis measurements were $1 \mathrm{mM}$ ABTS and $0.05 \mu \mathrm{g} / \mathrm{mL}$ HRP). Also, $350 \mu \mathrm{L}$ of the filtered catalytic reaction solution was added to $8 \mu \mathrm{L}$ of $40 \mathrm{mM}$ $\mathrm{TMB}$ and $50 \mu \mathrm{L}$ of $0.4 \mu \mathrm{g} / \mathrm{mL}$ HRP (final concentrations after dilutions for UV-Vis measurements were $0.8 \mathrm{mM} \mathrm{TMB}$ and $0.05 \mu \mathrm{g} / \mathrm{mL}$ HRP). The oxidation produced a blue color with a maximum absorbance centered at $652 \mathrm{~nm}$. Acetate/Acetic acid buffer solutions $(0.2 \mathrm{M}, 0.2 \mathrm{~mL})$ were prepared combining $5.4 \mathrm{~g}$ sodium acetate trihydrate $+1.2 \mathrm{~mL}$ glacial acetic acid in $198.8 \mathrm{~mL}$ water. Recycling experiments carried out after one hour reaction runs included 2 centrifuge cycles and redispersion in water prior to the addition of fresh glucose solutions. This process was repeated prior to each reuse.

\subsection{Catalyst Characterization}

The textural properties of the MCM-41 materials were determined from nitrogen adsorption isotherms measured by an ASAP 2020 instrument (Micromeritics, Norcross, GA, USA). The samples were out-gassed at $26.7 \mathrm{~Pa}$ and $623 \mathrm{~K}$ for $6 \mathrm{~h}$ before the measurement. The amount of amine groups grafted onto silica surface was determined by thermogravimetric analysis (SDTA-851 equipment, Mettler Toledo, Barcelona, Spain). Samples of ca. $3 \mathrm{mg}$ were heated at $5^{\circ} \mathrm{C} / \mathrm{min}$ up to $800{ }^{\circ} \mathrm{C}$ ) under synthetic air flow. The morphologies, size distribution and crystalline structure of these materials were determined by Transmission Electron Microscopy (TEM) in a T20 (Tecnai, Thermo Fisher, Hillboro, OR, USA) and Titan Cube (FEI, Thermo Fisher, Hillboro, OR, USA) system operated at 200-300 kV, respectively, and coupled with a CCD camera (Gatan, CA, USA). The samples for TEM analysis were prepared by suspension of the corresponding sample in water, dropping the suspension onto a 200-mesh carbon-coated copper grid (Electron Microscopy Sciences, Hatfield, PA, USA) and letting it dry under ambient air with the aid of anti-capillary tweezers. The UV-vis absorption spectra of the products of reaction were systematically recorded using a V-67 UV/Visible spectrophotometer (JASCO, Madrid, Spain) using a quartz cell of $1 \mathrm{~cm}$ light path.

\section{Conclusions}

Au NPs supported onto mesoporous silica supports via electrostatic attraction represents a feasible and straightforward strategy to fabricate glucose-oxidase enzyme-like inorganic platforms able to deliver a successful performance under mild reaction conditions (neutral $\mathrm{pH}$ and temperature).

Author Contributions: Data curation, M.C.O.-L. and J.L.H.; Formal analysis, J.L.H. and J.S.; Funding acquisition, J.S.; Investigation, M.C.O.-L., J.L.H. and J.S.; Methodology, J.L.H. and J.S.; Project administration, J.S.; Resources, J.S.; Supervision, J.L.H. and J.S.; Validation, J.B.-A.; Visualization, J.B.-A. and J.L.H.; Writing-Original draft, J.L.H.; Writing-Review \& editing, M.C.O.-L., J.B.-A. and J.L.H. All authors have read and agreed to the published version of the manuscript.

Funding: This research was funded by the European Research Council through an Advanced Grant (CADENCE, grant number 742684). The APC was waived by the journal.

Acknowledgments: Financial support from the European Research Council (ERC Advanced Grant CADENCE number 742684) is gratefully acknowledged. The TEM measurements were conducted at the Laboratorio de Microscopias Avanzadas, Instituto de Nanociencia de Aragon, Universidad de Zaragoza, Spain. The synthesis of materials has been performed by the Platform of Production of Biomaterials and Nanoparticles of the NANOBIOSIS ICTS, more specifically by the Nanoparticle Synthesis Unit of the CIBER in BioEngineering, Biomaterials \& Nanomedicine (CIBER-BBN). J.B-A. acknowledges the Spanish Government for an FPU predoctoral contract. 
Conflicts of Interest: The authors declare no conflict of interest.

\section{References}

1. Gallezot, P. Conversion of biomass to selected chemical products. Chem. Soc. Rev. 2012, 41, 1538-1558. [CrossRef] [PubMed]

2. Kobayashi, H.; Fukuoka, A. Synthesis and utilisation of sugar compounds derived from lignocellulosic biomass. Green Chem. 2013, 15, 1740-1763. [CrossRef]

3. Xue, Z.; Ma, M.-G.; Li, Z.; Mu, T. Advances in the conversion of glucose and cellulose to 5-hydroxymethylfurfural over heterogeneous catalysts. RSC Adv. 2016, 6, 98874-98892. [CrossRef]

4. Kusema, B.T.; Murzin, D.Y. Catalytic oxidation of rare sugars over gold catalysts. Catal. Sci. Technol. 2013, 3, 297-307. [CrossRef]

5. Pal, P.; Kumar, R.; Banerjee, S. Manufacture of gluconic acid: A review towards process intensification for green production. Chem. Eng. Process. Process. Intensif. 2016, 104, 160-171. [CrossRef]

6. Wu, J.J.X.; Wang, X.Y.; Wang, Q.; Lou, Z.P.; Li, S.R.; Zhu, Y.Y.; Qin, L.; Wei, H. Nanomaterials with enzyme-like characteristics (nanozymes): Next-generation artificial enzymes (II). Chem. Soc. Rev. 2019, 48, 1004-1076. [CrossRef]

7. Yu, S.; Chen, Z.; Zeng, X.; Chen, X.; Gu, Z. Advances in nanomedicine for cancer starvation therapy. Theranostics 2019, 9, 8026-8047. [CrossRef]

8. Huo, M.; Wang, L.; Chen, Y.; Shi, J. Tumor-selective catalytic nanomedicine by nanocatalyst delivery. Nat. Commun. 2017, 8, 357. [CrossRef]

9. Baldim, V.; Bedioui, F.; Mignet, N.; Margaill, I.; Berret, J.F. The enzyme-like catalytic activity of cerium oxide nanoparticles and its dependency on $\mathrm{Ce}^{3+}$ surface area concentration. Nanoscale 2018, 10, 6971-6980. [CrossRef]

10. Lin, Y.H.; Ren, J.S.; Qu, X.G. Catalytically Active Nanomaterials: A Promising Candidate for Artificial Enzymes. Acc. Chem. Res. 2014, 47, 1097-1105. [CrossRef]

11. Gao, L.Z.; Zhuang, J.; Nie, L.; Zhang, J.B.; Zhang, Y.; Gu, N.; Wang, T.H.; Feng, J.; Yang, D.L.; Perrett, S.; et al. Intrinsic peroxidase-like activity of ferromagnetic nanoparticles. Nat. Nanotechnol. 2007, 2, 577-583. [CrossRef]

12. Jiang, D.W.; Ni, D.L.; Rosenkrans, Z.T.; Huang, P.; Yan, X.Y.; Cai, W.B. Nanozyme: New horizons for responsive biomedical applications. Chem. Soc. Rev. 2019, 48, 3683-3704. [CrossRef]

13. Li, L.; Yang, Z.; Fan, W.; He, L.; Cui, C.; Zou, J.; Tang, W.; Jacobson, O.; Wang, Z.; Niu, G.; et al. In Situ Polymerized Hollow Mesoporous Organosilica Biocatalysis Nanoreactor for Enhancing ROS-Mediated Anticancer Therapy. Adv. Funct. Mater. 2019. [CrossRef]

14. Fan, L.; Tian, Y.; Lou, D.; Wu, H.; Cui, Y.; Gu, N.; Zhang, Y. Catalytic gold-platinum alloy nanoparticles and a novel glucose oxidase mimic with enhanced activity and selectivity constructed by molecular imprinting. Anal. Methods 2019, 11, 4586-4592.

15. Li, J.; Liu, W.; Wu, X.; Gao, X. Mechanism of $\mathrm{pH}$-switchable peroxidase and catalase-like activities of gold, silver, platinum and palladium. Biomaterials 2015, 48,37-44. [CrossRef]

16. Ali, S.S.; Hardt, J.I.; Quick, K.L.; Kim-Han, J.S.; Erlanger, B.F.; Huang, T.-T.; Epstein, C.J.; Dugan, L.L. A biologically effective fullerene (C60) derivative with superoxide dismutase mimetic properties. Free Radic. Biol. Med. 2004, 37, 1191-1202. [CrossRef]

17. Wu, Y.-S.; Huang, F.-F.; Lin, Y.-W. Fluorescent Detection of Lead in Environmental Water and Urine Samples Using Enzyme Mimics of Catechin-Synthesized Au Nanoparticles. ACS Appl. Mater. Interfaces 2013, 5, 1503-1509. [CrossRef]

18. Shen, X.M.; Liu, W.Q.; Gao, X.J.; Lu, Z.H.; Wu, X.C.; Gao, X.F. Mechanisms of Oxidase and Superoxide Dismutation-like Activities of Gold, Silver, Platinum, and Palladium, and Their Alloys: A General Way to the Activation of Molecular Oxygen. J. Am. Chem. Soc. 2015, 137, 15882-15891. [CrossRef]

19. Fan, L.; Lou, D.D.; Wu, H.A.; Zhang, X.Z.; Zhu, Y.F.; Gu, N.; Zhang, Y. A Novel AuNP-Based Glucose Oxidase Mimic with Enhanced Activity and Selectivity Constructed by Molecular Imprinting and O-2-Containing Nanoemulsion Embedding. Adv. Mater. Interfaces 2018, 5, 1801070. [CrossRef]

20. Chen, L.; Sha, L.; Qiu, Y.; Wang, G.; Jiang, H.; Zhang, X. An amplified electrochemical aptasensor based on hybridization chain reactions and catalysis of silver nanoclusters. Nanoscale 2015, 7, 3300-3308. [CrossRef] 
21. Wu, G.-W.; He, S.-B.; Peng, H.-P.; Deng, H.-H.; Liu, A.-L.; Lin, X.-H.; Xia, X.-H.; Chen, W. Citrate-Capped Platinum Nanoparticle as a Smart Probe for Ultrasensitive Mercury Sensing. Anal. Chem. 2014, 86, 10955-10960. [CrossRef]

22. Lan, J.; Xu, W.; Wan, Q.; Zhang, X.; Lin, J.; Chen, J.; Chen, J. Colorimetric determination of sarcosine in urine samples of prostatic carcinoma by mimic enzyme palladium nanoparticles. Anal. Chim. Acta 2014, 825, 63-68. [CrossRef]

23. Biella, S.; Prati, L.; Rossi, M. Selective Oxidation of D-Glucose on Gold Catalyst. J. Catal. 2002, 206, $242-247$. [CrossRef]

24. Li, L.; Zhang, L.; Carmona, U.; Knez, M. Semi-artificial and bioactive ferroxidase with nanoparticles as the active sites. Chem. Commun. 2014, 50, 8021-8023. [CrossRef]

25. Periasamy, A.P.; Roy, P.; Wu, W.-P.; Huang, Y.-H.; Chang, H.-T. Glucose Oxidase and Horseradish Peroxidase Like Activities of Cuprous Oxide/Polypyrrole Composites. Electrochim. Acta 2016, 215, 253-260. [CrossRef]

26. Zhang, H.; Lu, L.; Kawashima, K.; Okumura, M.; Haruta, M.; Toshima, N. Synthesis and Catalytic Activity of Crown Jewel-Structured (IrPd)/Au Trimetallic Nanoclusters. Adv. Mater. 2015, 27, 1383-1388. [CrossRef]

27. Khawaji, M.; Zhang, Y.; Loh, M.; Graça, I.; Ware, E.; Chadwick, D. Composition dependent selectivity of bimetallic Au-Pd NPs immobilised on titanate nanotubes in catalytic oxidation of glucose. Appl. Catal. B Environ. 2019, 256, 117799. [CrossRef]

28. Zhang, X.; Shi, H.; Chi, Q.; Liu, X.; Chen, L. Cellulose-supported Pd nanoparticles: Effective for the selective oxidation of glucose into gluconic acid. Polym. Bull. 2019, 77, 1003-1014. [CrossRef]

29. Comotti, M.; Pina, C.D.; Rossi, M. Mono- and bimetallic catalysts for glucose oxidation. J. Mol. Catal. A Chem. 2006, 251, 89-92. [CrossRef]

30. Jin, X.; Zhao, M.; Shen, J.; Yan, W.; He, L.; Thapa, P.S.; Ren, S.; Subramaniam, B.; Chaudhari, R.V. Exceptional performance of bimetallic $\mathrm{Pt}_{1} \mathrm{Cu}_{3} / \mathrm{TiO}_{2}$ nanocatalysts for oxidation of gluconic acid and glucose with $\mathrm{O}_{2}$ to glucaric acid. J. Catal. 2015, 330, 323-329. [CrossRef]

31. Zhang, H.; Toshima, N. Preparation of novel Au/Pt/Ag trimetallic nanoparticles and their high catalytic activity for aerobic glucose oxidation. Appl. Catal. A Gen. 2011, 400, 9-13. [CrossRef]

32. Bönnemann, H.; Brijoux, W.; Tilling, A.S.; Siepen, K. Application of heterogeneous colloid catalysts for the preparation of fine chemicals. Top. Catal. 1997, 4, 217-227. [CrossRef]

33. Baatz, C.; Decker, N.; Pruse, U. New innovative gold catalysts prepared by an improved incipient wetness method. J. Catal. 2008, 258, 165-169. [CrossRef]

34. Greer, A. Christopher Foote's discovery of the role of singlet oxygen O-1(2) ((1)Delta(g)) in photosensitized oxidation reactions. Acc. Chem. Res. 2006, 39, 797-804. [CrossRef]

35. Ishida, T.; Kinoshita, N.; Okatsu, H.; Akita, T.; Takei, T.; Haruta, M. Influence of the support and the size of gold clusters on catalytic activity for glucose oxidation. Angew. Chem. Int. Ed. Engl. 2008, 47, 9265-9268. [CrossRef]

36. Benkó, T.; Beck, A.; Geszti, O.; Katona, R.; Tungler, A.; Frey, K.; Guczi, L.; Schay, Z. Selective oxidation of glucose versus CO oxidation over supported gold catalysts. Appl. Catal. A Gen. 2010, 388, 31-36. [CrossRef]

37. Cao, Y.; Liu, X.; Iqbal, S.; Miedziak, P.J.; Edwards, J.K.; Armstrong, R.D.; Morgan, D.J.; Wang, J.; Hutchings, G.J. Base-free oxidation of glucose to gluconic acid using supported gold catalysts. Catal. Sci. Technol. 2016, 6, 107-117. [CrossRef]

38. Megías-Sayago, C.; Bobadilla, L.F.; Ivanova, S.; Penkova, A.; Centeno, M.A.; Odriozola, J.A. Gold catalyst recycling study in base-free glucose oxidation reaction. Catal. Today 2018, 301, 72-77. [CrossRef]

39. Megías-Sayago, C.; Ivanova, S.; López-Cartes, C.; Centeno, M.A.; Odriozola, J.A. Gold catalysts screening in base-free aerobic oxidation of glucose to gluconic acid. Catal. Today 2017, 279, 148-154. [CrossRef]

40. Okatsu, H.; Kinoshita, N.; Akita, T.; Ishida, T.; Haruta, M. Deposition of gold nanoparticles on carbons for aerobic glucose oxidation. Appl. Catal. A Gen. 2009, 369, 8-14. [CrossRef]

41. Baatz, C.; Pruse, U. Preparation of gold catalysts for glucose oxidation by incipient wetness. J. Catal. 2007, 249, 34-40. [CrossRef]

42. Guo, S.; Fang, Q.; Li, Z.; Zhang, J.; Zhang, J.; Li, G. Efficient base-free direct oxidation of glucose to gluconic acid over TiO2-supported gold clusters. Nanoscale 2019, 11, 1326-1334. [CrossRef]

43. Ishida, T.; Kuroda, K.; Kinoshita, N.; Minagawa, W.; Haruta, M. Direct deposition of gold nanoparticles onto polymer beads and glucose oxidation with H2O2. J. Colloid Interface Sci. 2008, 323, 105-111. [CrossRef] 
44. Jv, Y.; Li, B.; Cao, R. Positively-charged gold nanoparticles as peroxidase mimic and their application in hydrogen peroxide and glucose detection. Chem. Commun. 2010, 46, 8017-8019. [CrossRef]

45. Pocker, Y.; Green, E. Hydrolysis of d-glucono-delta-lactone. I. General acid-base catalysis, solvent deuterium-isotope effects, and transition-state characterization. J. Am. Chem. Soc. 1973, 95, 113-119. [CrossRef]

46. Cattaneo, S.; Stucchi, M.; Villa, A.; Prati, L. Gold Catalysts for the Selective Oxidation of Biomass-Derived Products. Chem CatChem 2018, 11, 309-323. [CrossRef]

47. Prüße, U.; Herrmann, M.; Baatz, C.; Decker, N. Gold-catalyzed selective glucose oxidation at high glucose concentrations and oxygen partial pressures. Appl. Catal. A Gen. 2011, 406, 89-93. [CrossRef]

48. Prüße, U.; Heidinger, S.; Baatz, C. Catalytic conversion of renewables: Kinetic and mechanistic aspects of the gold-catalyzed liquid-phase glucose oxidation. vTI Agric. For. Res. 2011, 16, 261-272.

49. Zieba, M.; Hueso, J.L.; Arruebo, M.; Martinez, G.; Santamaria, J. Gold-coated halloysite nanotubes as tunable plasmonic platforms. New J. Chem. 2014, 38, 2037-2042. [CrossRef]

50. Lin, Y.; Li, Z.; Chen, Z.; Ren, J.; Qu, X. Mesoporous silica-encapsulated gold nanoparticles as artificial enzymes for self-activated cascade catalysis. Biomaterials 2013, 34, 2600-2610. [CrossRef]

51. Beltrame, P.; Comotti, M.; Della Pina, C.; Rossi, M. Aerobic oxidation of glucose II. Catalysis by colloidal gold. Appl. Catal. A-Gen. 2006, 297, 1-7. [CrossRef]

52. Wang, Y.; Van de Vyver, S.; Sharma, K.K.; Román-Leshkov, Y. Insights into the stability of gold nanoparticles supported on metal oxides for the base-free oxidation of glucose to gluconic acid. Green Chem. 2014, 16, 719-726. [CrossRef]

53. Qi, P.; Chen, S.; Chen, J.; Zheng, J.; Zheng, X.; Yuan, Y. Catalysis and Reactivation of Ordered Mesoporous Carbon-Supported Gold Nanoparticles for the Base-Free Oxidation of Glucose to Gluconic Acid. ACS Catal. 2015, 5, 2659-2670. [CrossRef]

54. Comotti, M.; Della Pina, C.; Matarrese, R.; Rossi, M. The catalytic activity of "naked" gold particles. Angew. Chem. Int. Ed. Engl. 2004, 43, 5812-5815. [CrossRef]

55. Della Pina, C.; Falletta, E.; Prati, L.; Rossi, M. Selective oxidation using gold. Chem. Soc. Rev. 2008, 37, 2077-2095. [CrossRef] [PubMed]

56. Comotti, M.; Pina, C.D.; Matarrese, R.; Rossi, M.; Siani, A. Oxidation of alcohols and sugars using Au/C catalysts. Appl. Catal. A Gen. 2005, 291, 204-209. [CrossRef]

57. Khawaji, M.; Chadwick, D. Au-Pd Bimetallic Nanoparticles Immobilised on Titanate Nanotubes: A Highly Active Catalyst for Selective Oxidation. ChemCatChem 2017, 9, 4353-4363. [CrossRef]

58. Datta, K.K.R.; Reddy, B.V.S.; Ariga, K.; Vinu, A. Gold Nanoparticles Embedded in a Mesoporous Carbon Nitride Stabilizer for Highly Efficient Three-Component Coupling Reaction. Angew. Chem. Int. Ed. 2010, 49, 5961-5965. [CrossRef]

59. Miguel-Sancho, N.; Martinez, G.; Sebastian, V.; Malumbres, A.; Florea, I.; Arenal, R.; Ortega-Liebana, M.C.; Hueso, J.L.; Santamaria, J. Pumping Metallic Nanoparticles with Spatial Precision within Magnetic Mesoporous Platforms: 3D Characterization and Catalytic Application. ACS Appl. Mater. Interfaces 2017, 9, 41529-41536. [CrossRef]

60. Ortega-Liebana, M.C.; Hueso, J.L.; Ferdousi, S.; Arenal, R.; Irusta, S.; Yeung, K.L.; Santamaria, J. Extraordinary sensitizing effect of co-doped carbon nanodots derived from mate herb: Application to enhanced photocatalytic degradation of chlorinated wastewater compounds under visible light. Appl. Catal. B Environ. 2017, 218, 68-79. [CrossRef]

61. Duff, D.G.; Baiker, A.; Edwards, P.P. A new hydrosol of gold clusters. J. Chem. Soc. Chem. Commun. 1993, 96-98. [CrossRef]

62. Hueso, J.L.; Sebastian, V.; Mayoral, A.; Uson, L.; Arruebo, M.; Santamaria, J. Beyond gold: Rediscovering tetrakis-(hydroxymethyl)-phosphonium chloride (THPC) as an effective agent for the synthesis of ultra-small noble metal nanoparticles and Pt-containing nanoalloys. RSC Adv. 2013, 3, 10427-10433. [CrossRef]

63. Uson, L.; Sebastian, V.; Mayoral, A.; Hueso, J.L.; Eguizabal, A.; Arruebo, M.; Santamaria, J. Spontaneous formation of Au-Pt alloyed nanoparticles using pure nano-counterparts as starters: A ligand and size dependent process. Nanoscale 2015, 7, 10152-10161. [CrossRef] [PubMed]

64. Talavera-Pech, W.A.; Esparza-Ruiz, A.; Quintana-Owen, P.; Vilchis-Nestor, A.R.; Carrera-Figueiras, C.; Avila-Ortega, A. Effects of different amounts of APTES on physicochemical and structural properties of amino-functionalized MCM-41-MSNs. J. Sol Gel Sci. Technol. 2016, 80, 697-708. [CrossRef] 
65. Gomez, L.; Hueso, J.L.; Ortega-Liebana, M.C.; Santamaria, J.; Cronin, S.B. Evaluation of gold-decorated halloysite nanotubes as plasmonic photocatalysts. Catal. Commun. 2014, 56, 115-118. [CrossRef]

66. Uson, L.; Hueso, J.L.; Sebastian, V.; Arenal, R.; Florea, I.; Irusta, S.; Arruebo, M.; Santamaria, J. In-Situ preparation of ultra-small Pt nanoparticles within rod-shaped mesoporous silica particles: 3-D tomography and catalytic oxidation of n-hexane. Catal. Commun. 2017, 100, 93-97. [CrossRef]

67. Vogel, W.; Duff, D.G.; Baiker, A. X-ray structure of a new hydrosol of gold clusters. Langmuir 1995, 11, 401-404. [CrossRef]

68. Westcott, S.L.; Oldenburg, S.J.; Lee, T.R.; Halas, N.J. Formation and adsorption of clusters of gold nanoparticles onto functionalized silica nanoparticle surfaces. Langmuir 1998, 14, 5396-5401. [CrossRef]

69. Pfeiffer, C.; Rehbock, C.; Huhn, D.; Carrillo-Carrion, C.; de Aberasturi, D.J.; Merk, V.; Barcikowski, S.; Parak, W.J. Interaction of colloidal nanoparticles with their local environment: The (ionic) nanoenvironment around nanoparticles is different from bulk and determines the physico-chemical properties of the nanoparticles. J. R. Soc. Interface 2014, 11, 20130931. [CrossRef]

70. Ortega-Liebana, M.C.; Hueso, J.L.; Arenal, R.; Santamaria, J. Titania-coated gold nanorods with expanded photocatalytic response. Enzyme-like glucose oxidation under near-infrared illumination. Nanoscale 2017, 9 , 1787-1792. [CrossRef]

71. Luo, W.J.; Zhu, C.F.; Su, S.; Li, D.; He, Y.; Huang, Q.; Fan, C.H. Self-Catalyzed, Self-Limiting Growth of Glucose Oxidase-Mimicking Gold Nanoparticles. ACS Nano 2010, 4, 7451-7458. [CrossRef] [PubMed]

72. Ortega-Liebana, M.C.; Hueso, J.L.; Fernandez-Pacheco, R.; Irusta, S.; Santamaria, J. Luminescent mesoporous nanorods as photocatalytic enzyme-like peroxidase surrogates. Chem. Sci. 2018, 9, 7766-7778. [CrossRef] [PubMed]

73. Liu, S.H.; Lu, F.; Xing, R.M.; Zhu, J.J. Structural Effects of $\mathrm{Fe}_{3} \mathrm{O}_{4}$ Nanocrystals on Peroxidase-Like Activity. Chem.-Eur. J. 2011, 17, 620-625. [CrossRef]

74. Cheng, P.; Wang, H.; Shi, X. The effect of phenylalanine ligands on the chiral-selective oxidation of glucose on $\mathrm{Au}(111)$. Nanoscale 2020, 12, 3050-3057. [CrossRef] [PubMed]

75. Ishchuk, O.P.; Sterner, O.; Strevens, H.; Ellervik, U.; Manner, S. The use of polyhydroxylated carboxylic acids and lactones to diminish biofilm formation of the pathogenic yeast Candida albicans. RSC Adv. 2019, 9, 10983-10989. [CrossRef]

76. Zhang, Y.A.; Jin, Y.L.; Cui, H.X.; Yan, X.Y.; Fan, K.L. Nanozyme-based catalytic theranostics. RSC Adv. 2020, 10, 10-20. [CrossRef]

77. Comotti, M.; Dellapina, C.; Falletta, E.; Rossi, M. Is the biochemical route always advantageous? The case of glucose oxidation. J. Catal. 2006, 244, 122-125. [CrossRef]

78. Chenouf, M.; Megías-Sayago, C.; Ammari, F.; Ivanova, S.; Centeno, M.; Odriozola, J. Immobilization of Stabilized Gold Nanoparticles on Various Ceria-Based Oxides: Influence of the Protecting Agent on the Glucose Oxidation Reaction. Catalysts 2019, 9, 125. [CrossRef]

79. Heutz, N.A.; Dolcet, P.; Birkner, A.; Casarin, M.; Merz, K.; Gialanella, S.; Gross, S. Inorganic chemistry in a nanoreactor: $\mathrm{Au} / \mathrm{TiO}_{2}$ nanocomposites by photolysis of a single-source precursor in miniemulsion. Nanoscale 2013, 5, 10534-10541. [CrossRef]

80. Balas, F.; Manzano, M.; Colilla, M.; Vallet-Regi, M. L-Trp adsorption into silica mesoporous materials to promote bone formation. Acta Biomater. 2008, 4, 514-522. [CrossRef]

81. Manzano, M.; Aina, V.; Arean, C.O.; Balas, F.; Cauda, V.; Colilla, M.; Delgado, M.R.; Vallet-Regi, M. Studies on MCM-41 mesoporous silica for drug delivery: Effect of particle morphology and amine functionalization. Chem. Eng. J. 2008, 137, 30-37. [CrossRef]

82. Eguizabal, A.; Uson, L.; Sebastian, V.; Hueso, J.L.; Pina, M.P. Efficient and facile tuning of Vulcan XC72 with ultra-small Pt nanoparticles for electrocatalytic applications. RSC Adv. 2015, 5, 90691-90697. [CrossRef]

(C) 2020 by the authors. Licensee MDPI, Basel, Switzerland. This article is an open access article distributed under the terms and conditions of the Creative Commons Attribution (CC BY) license (http://creativecommons.org/licenses/by/4.0/). 